Jurnal Ayurveda Medistra
ISSN. 2656-3142| Volume 3 Nomor 1 | Februari 2021 | pages:1-10
Avalaible online at http://ojs.stikesmedistra-indonesia.ac.id/

\title{
DETERMINAN PERILAKU PENCEGAHAN PERDARAHAN PASCA PERSALINAN
}

\author{
Harmatuti \\ Program Studi Kebidanan (D3 ) STIKes Bani Saleh, harmatuti77@gmail.com, 081310217745
}

\begin{abstract}
Abstrak
Perdarahan pasca persalinan masih tinggi kejadiannya dikarenakan masih rendahnya perilaku pencegahan yang dilakukan saat masa kehamilan. Beberapa upaya yang dapat mengurangi gangguan fisik maupun psikis seperti promosi hidup sehat serta deteksi awal dapat diterapkan dalam strategi pencegahan perdarahan pasca persalinan. Penelitian ini bertujuan mengetahui pengaruh pemberdayaan, peran suami, peran peer group, status kesehatan, pengetahuan dan sikap terhadap perilaku ibu hamil dalam pencegahan perdarahan pasca persalinan di RS Kesdam Cijantung Tahun 2019. Metode penelitian yang digunakan yaitu kuantitatif dengan desain cross-sectional. Analisis data menggunakan smartPLS 2.0 dan SPSS 18. Hasil pengujian hipotesis menggunakan Structural Equation Modelling (SEM) temuan penelitian yakni pemberdayaan (16,58\%), peran suami $(4,8 \%)$, peran peer group $(18,30 \%)$, status kesehatan $(24,37 \%)$, pengetahuan $(10,07 \%)$ dan sikap $(10,50 \%)$, pengaruh langsung perilaku ibu hamil dalam pencegahan perdarahan pasca persalinan sebesar $84,61 \%$, dan pengaruh tidak langsung sebesar $1,1 \%$. Status kesehatan merupakan faktor dominan yang sangat mempengaruhi perilaku ibu hamil dalam pencegahan perdarahan pasca persalinan. Peneliti menyarankan agar beberapa pihak bekerja sama untuk membantu ibu hamil dalam pencegahan perdarahan pasca persalinan.
\end{abstract}

Kata kunci : ibu hamil perilaku pencegahan, perdarahan pasca persalinan.

\begin{abstract}
Postpartum hemorrhage is still high in incidence due to the low prevention behavior during pregnancy. Several efforts that can reduce physical and psychological disorders such as promotion of a healthy life and early detection can be applied in strategies to prevent postpartum bleeding. This study aims to determine the effect of empowerment, the role of husbands, the role of peer groups, health status, knowledge and attitudes on the behavior of pregnant women in preventing postpartum hemorrhage at the Kesdam Cijantung Hospital in 2019. The research method used is quantitative with cross-sectional design. Data analysis using smartPLS 2.0 and SPSS 18. The results of hypothesis testing using Structural Equation Modeling (SEM) research findings are empowerment (16.58\%), husband's role (4.8\%), peer group role (18.30\%), status health (24.37\%), knowledge (10.07\%) and attitudes (10.50\%), the direct effect of the behavior of pregnant women in preventing postpartum bleeding was $84.61 \%$, and the indirect effect was $1.1 \%$. Health status is the dominant factor that greatly influences the behavior of pregnant women in preventing postpartum bleeding. Researchers suggest that several parties work together to assist pregnant women in preventing postpartum bleeding.
\end{abstract}

Keywords: pregnant women preventative behavior, post partum hemorrhage. 


\section{PENDAHULUAN}

Isu global yang merupakan masalah utama di seluruh negara yaitu mortalitas ibu atau disebut AKI (Angka Kematian Ibu). Penurunan angka kematian ibu di Indonesia yaitu sebesar 359/100.000 kelahiran hidup ini belum bisa mencapai target Sustainable Development Goals (SDGs) tahun 2018 yang diterapkan di seluruh negara, target angka kematian ibu adalah 70/100.000 kelahiran hidup. ${ }^{(1)}$

Angka kematian ibu yang terjadi di Indonesia angka tertinggi sebesar $42 \%$ ialah perdarahan setelah persalinan, hal tersebut sesuai hasil survei yang telah dilakukan SDKI. ${ }^{(2)}$ Mortalitas ibu di DKI Jakarta terbesar penyebabnya merupakan perdarahan post partum. ${ }^{(3)}$ Kejadian perdarahan pasca partum bersifat multifaktorial yaitu karena obstetri klinis, obstetri sosial, obstetri buruk, jarak kehamilan kurang dari dua tahun, ditemukannya hemoglobin kurang normal saat wanita hamil trimester yang ke-3 dan pencegahannnya dapat dilakukan lebih dini melalui hasil pemeriksaan status kesehatan ibu hamil tersebut. ${ }^{(4)}$

Perilaku pencegahan dini sebagai cara mencegah perdarahan setelah persalinan yaitu dapat dilakukannya pemberdayaan pada ibu hamil melalui konseling dengan melibatkan peran suami, peran peer group sesama hamil sebagai salah cara menerima info seputar kehamilan khususnya mencegah hemoglobin yang kurang dalam kehamilan, mengurangi gangguan fisik maupun psikis. ${ }^{(5)}$ Pemberdayaan melalui konseling meningkatkan pengetahuannya, memperbaiki sikap positif serta perilaku wanita hamil. ${ }^{(6)}$ Penggunaan metode konseling efektif dan mengena akan meningkatkan pengetahuan ibu hamil mengenai faktor risiko perdarahan pasca persalinan. ${ }^{(7)}$ Tingkat status kesehatan seseorang atau ibu hamil yang baik, maka pengetahuannya akan menjadi semakin baik. (8)

Rekomendasi WHO yaitu dalam preventif perdarahan pasca persalinan adalah melalui pemeriksaan hemoglobin mulai awal kehamilan triwulan pertama, suplementasi besi selama 90 hari kehamilan, program pemberdayaan ibu hamil melalui konseling dan gaya hidup ibu hamil. ${ }^{(9)}$ Peran suami untuk istrinya yaitu akan dapat meningkatkan kepercayaan diri istrinya disaat masa kehamilannya, istri lebih berbahagia serta menjadi lebih siap menjalani kehamilannya, persiapan kelahiran dan setelahnya. ${ }^{(9)}$ Dukungan fisik dan psikologis berdampak pada sikap positif, diharapkan ibu hamil dapat merawat kehamilannya sampai dengan persalinannya. ${ }^{(10)}$. Peranan peer group bagi wanita yang hamil dapat meningkatkan pengetahuannya mengenal perdarahan pasca persalinan, didapatkan dari komunikasi, pemberitaan serta edukasi dari kalangan sebaya yang biasa disebut juga teman sesama hamil. ${ }^{(1)}$

Data rekam medik Rumah Sakit Kesdam Cijantung Jakarta periode satu tahun yaitu tahun 2018 sebanyak $30 \%$ persalinan terjadi perdarahan pasca persalinan, ini belum mencapai target yang ditetapkan RS Kesdam tahun 2018 yaitu tidak terjadinya perdarahan pasca persalinan bagi semua ibu bersalin di RS Kesdam Cijantung Jakarta. Wawancara kepada beberapa bidan dan perawat, mengatakan bahwa perdarahan pasca partum penyebabnya dari wanita hamil dengan kadar $\mathrm{Hb}$ yang kurang dari normal, hamil tidak dikehendaki, paritas / jumlah kelahiran tiga kali atau lebih, serta riwayat kesehatan wanita wanita hamil yang tidak baik.

Wawancara melalui beberapa ibu pasca persalinan di RS Kesdam dengan riwayat perdarahan pasca persalinan mereka mengatakan kurang tahu adanya upaya preventif dengan perilaku mencegah perdarahan pasca persalinan yang dapat dilakukan lebih lebih awal yaitu saat hamil, ini diungkapkan dalam pernyataanya yaitu ibu hanya mengerti bahwa perdarahan tersebut tiba-tiba terjadi, tidak dapat dilakukan pencegahannya saat hamil, hanya dokter, bidan yang dapat mengatasi perdarahannya. Dari fenomena yang terjadi perlu dilakukannya penelitian mengenai pengaruh pemberdayaan, peran peer group, peran 
suami, pengetahuan, status kesehatan, sikap terhadap perilaku ibu hamil dalam pencegahan perdarahan pasca persalinan di Rumah Sakit Kesdam Cijantung Jakarta.

Dilakukannya penelitian ini untuk mengetahui pengaruh langsung dan pengaruh tidak langsung serta besaran antara pemberdayaan, peran suami, peran peer group, status kesehatan, pengetahuan dan sikap terhadap perilaku ibu hamil dalam pencegahan perdarahan pasca persalinan di Rumah Sakit Kesdam Cijantung Jakarta. Penelitian ini berfokus pada pengaruh perilaku ibu hamil dalam pencegahan perdarahan post partum meliputi variabel pemberdayaan, peran peer group, peran suami, status kesehatan, pengetahuan dan sikap ibu hamil di Rumah Sakit Kesdam Cijantung Jakarta tahun 2019.

\section{METODE}

Penelitian ini kuantitatif, metode deskriptif analitik desain crossectional, dilakukan untuk kurun waktu yang bersamaan, tujuannya yaitu menganalisis hubungan sebab akibat antara variabel-variabel melalui uji hipotesis dengan menganalisis pengaruh langsung dan tidak langsung serta besaran antara pemberdayaan, peran suami, peran peer group, status kesehatan, pengetahuan dan sikap terhadap perilaku ibu hamil dalam pencegahan perdarahan pasca persalinan.

Jumlah sampel dalam penelitian diambil menurut kaidah jumlah sampel Partial Least Squares (PLS) yaitu kelipatan dari jumlah indikator yang akan diteliti. Menurut alat analisisnya yaitu menggunakan Structural Equation Modeling (SEM), maka penentuan sampel representative menurut Hair et.al bahwa total indikator minimal dikalikan 5, maksimal dikalikan 10. Total indikator penelitian yaitu 21, sehingga diperoleh sampel minimal 105 orang dan maksimal 210 orang, dalam hal ini peneliti mengambil sampel 105 ibu hamil.

Teknik pengambilan sampel menggunakan non random sampling dengan teknik purposive sampling. Kriteria inklusi yaitu semua ibu hamil trimester ke-3 (usia kehamilan 28-40 minggu) yang periksa hamil atau melakukan ante natal care di Rumah Sakit Kesdam Cijantung Jakarta, bersedia menjadi responden, dapat membaca dan menulis, serta dapat menggunakan bahasa
Indonesia. Data primer diperoleh dari RS Kesdam Cijantung Jakarta meliputi pemberdayaan, peran suami, peran peer group, status kesehatan, pengetahuan, sikap dan perilaku ibu hamil terhadap pencegahan perdarahan pasca persalinan dianggap relevan dengan tujuan penelitian.

Pengukuran meliputi variabel endogen dan variabel eksogen, skala yang digunakan yaitu skala interval, sedangkan teknik pengukurannya menggunakan semantic differential, yang memiliki skala 5 point, penilaian skala tersebut mulai dari sifat positif diberikan nilai terbesar sampai dengan sifat negatif diberikan nilai paling kecil. ${ }^{(12)}$

Untuk pengujian validitas dan reliabilitas yaitu meliputi indikator variabel endogen dan eksogen menggunakan PLS dinyatakan valid dengan loading factor yang direkomendasikan diatas 0,7. Dikatakan reliabel jika nilai Alpha Cronbach $(A C)>0,6$ bahkan semakin baik jika nilainya mendekati angka 1 . Sebaliknya jika nilai $A C<0,6$ maka instrumen yang digunakan tidak reliabel. Pengolahan data responden menggunakan program PLS. Kode angka setiap jawaban adalah 1-5 (untuk mempersingkat proses input data). Sedangkan analisis data dilakukan dengan PLS dengan metode analisis yang powerfull dikarenakan tidak banyak asumsi. (13)

Model refleksi berasumsi bahwa konstruk (variabel laten) dapat mempengaruhi indikator atau arah hubungan kausalitas dari konstruk ke indikator untuk penelitian ini pada variabel pemberdayaan, peran suami, peran peer group, status kesehatan, pengetahuan serta variabel sikap. Dalam kenyataannya variabel laten yaitu dari indikator-indikator yang bersifat formatif (mengarah ke hubungan kausal dari indikator ke konstruk), untuk penelitian di sini adalah perilaku ibu hamil dalam pencegahan perdarahan pasca persalinan. Adanya resiko dan dampak yang muncul dalam penelitian, setelah penelitian mendapat izin, maka peneliti menerapkan masalah etika melalui prosedur etika penenelitian. ${ }^{(14)}$

Data penyajian analisa SEM dari pengolahan data output yang menggunakan bantuan Smart PLS 2.0, ditampilkan menngunakan diagram, tabel dan lain-lain. ${ }^{(12)}$. 
Kemudian dianalisis dengan bantuan PLS untuk melihat apakah ada pengaruhnya pemberdayaan, peran suami, peran peer group, status kesehatan, pengetahuan dan sikap terhadap perilaku ibu hamil dalam pencegahan perdarahan setelah persalian.

PLS mempunyai jalur model analisis variabel laten memiliki 3 set hubungan antara variabel laten (structural model) yaitu (1) Inner Model diukur menggunakan Q-square predictive relevance yang rumusnya yaitu $\mathrm{Q}^{2}=$ $1-\left(1-\mathrm{R}_{\mathrm{I}}^{2}\right)\left(1-\mathrm{R}_{\mathrm{P}}^{2}\right)$, (2) Outer Model yaitu dengan mengkhususkan hubungan variabel laten dengan indikatornya (measurement model), diukur melalui convergent validity dan discriminant validity. Convergent validity nilai loading 0,5 sampai 0,6 dinilai cukup, jumlah indikator variabel laten adalah 3-7, untuk discriminant validity direkomendasikan nilai AVE adalah >0,5. (3) Weight relation atau nilai kasus variabel laten tetap diperkirakan atau estimasi. Tanpa menghilangkan generalisasi diasumsikan variabel laten, indikator atau manifest variabel skala zero means dan unit variance sehingga parameter lokasi (parameter konstanta) dapat dihilangkan dengan model. Tstatistik > 1,96 dapat disimpulkan adanya pengaruh yang signifikan, namun sebaliknya, jika T-statistik < 1,96, didapatkan kesimpulannya yaitu tidak mempunyai pengaruh yang signifikan. ${ }^{(12)}$

\section{HASIL}

Hasil penelitian menunjukkan bahwa mayoritas responden berada pada usia 20 - 35 tahun yaitu sebesar $80,0 \%$. Sebagian besar responden mempunyai pendidikan pada jenjang SMA sebanyak 75,2\%. Variabel perilaku pencegahan diukur menggunakan 15 butir pertanyaan, penilaian 1-5, nilai kuesioner yaitu 15-75 dan nilai aktualnya antara 36-75, untuk nilai rata-rataya 63,00 , median 65,00 serta standar deviasi 10,01. Variabel pemberdayaan diukur dengan 15 butir pertanyaan, penilaian $1-5$, penilaian kuisioner yaitu $15-75$, penilaian aktual antara $35-74$, nilai rata-ratanya 62,62 , nilai median 66,00 serta nilai standar deviasi 9,88 . Variabel peran suami pengukurannya dengan 15 butir pertanyaaan dengan penilaian 1-5, penilaian kuisioner antara 15-75 dan penilaian aktual antara 35-74, dengan rata-rata yang didapatkan sebesar 60,57 , nilai median 64,00 serta nilai standar deviasinya
10,43 . Untuk variabel peran peer group pengukurannya dengan 15 butir pertanyaan dengan nilai $15-75$, nilai aktual antara 35-74 dengan nilai rata-ratanya sebesar 62,04 , nilai medianya sebesar 64,00 dan nilai standar deviasi sebesar 9,56. Variabel pengetahuan pengukurannya melalui 15 butir pertanyaan dengan nilai 1-5, penilaian kuisioner antara 1575 dan penilaian aktual antara 36-75, nilai rataratanya 62,45 , nilai median 65,00 serta nilai standar deviasi sebesar 10,21.

Variabel status kesehatan dalam penelitian ini pengukurannya melalui 15 butir pertanyaan dengan nilai $1-5$, penilaian kuisioner adalah 15-75 dan penilaian aktual yaitu antara 36-75, untuk nilai rata-ratanya 61,68 dan nilai median 63,00 serta nilai standar deviasi sebesar 9,79 . Untuk variabel sikap dalam penelitian ini pengukurannya melalui 15 butir pernyataan dengan nilai $1-5$, penilaian kuisioner yaitu antara 15-75 dan penilaian aktual yaitu antara $35-74$, nilai rata-ratanya sebesar 63,00 , nilai mediannya 60,23 , serta nilai standar deviasi 10,84. Disimpulkan bahwa nilai akar kuadrat $A V E>$ dari nilai square root of average variance extracted (AVE) setiap konstruk, sehingga evaluasi pengukuran model memiliki discriminant validity yang baik.

Nilai $R$-square pemberdayaan berkontribusi terhadap peran suami sebesar $67,66 \%$ sedangkan sebesar $32,34 \%$ dijelaskan oleh variabel lain yang tidak diteliti. Pemberdayaan berkontribusi terhadap peran peer group sebesar 76,08\% sedangkan $23,92 \%$ dijelaskan oleh variabel lain yang tidak diteliti. Pemberdayaan berkontribusi terhadap pengetahuan sebesar $80,79 \%$ sedangkan $19,21 \%$ dijelaskan oleh variabel lain yang tidak diteliti. Pemberdayaan dan pengetahuan berkontribusi terhadap status kesehatan sebesar $78,56 \%$ sedangkan $21,44 \%$ dijelaskan oleh variabel lain yang tidak diteliti. Pemberdayaan, peran suami, peran peer group dan pengetahuan berkontribusi terhadap sikap sebesar 85,94\% sedangkan sebesar 14,06\% dijelaskan oleh variabel lain yang tidak diteliti. Pemberdayaan, peran suami, peran peer group, pengetahuan, status kesehatan serta sikap berkontribusi terhadap perilaku pencegahan sebesar $84,61 \%$, sedangkan sebesar $15,39 \%$ dijelaskan oleh variabel lain yang tidak ada di dalam penelitian.

Hasil evaluasi outer model dapat dilihat pada gambar 1 berikut ini: 


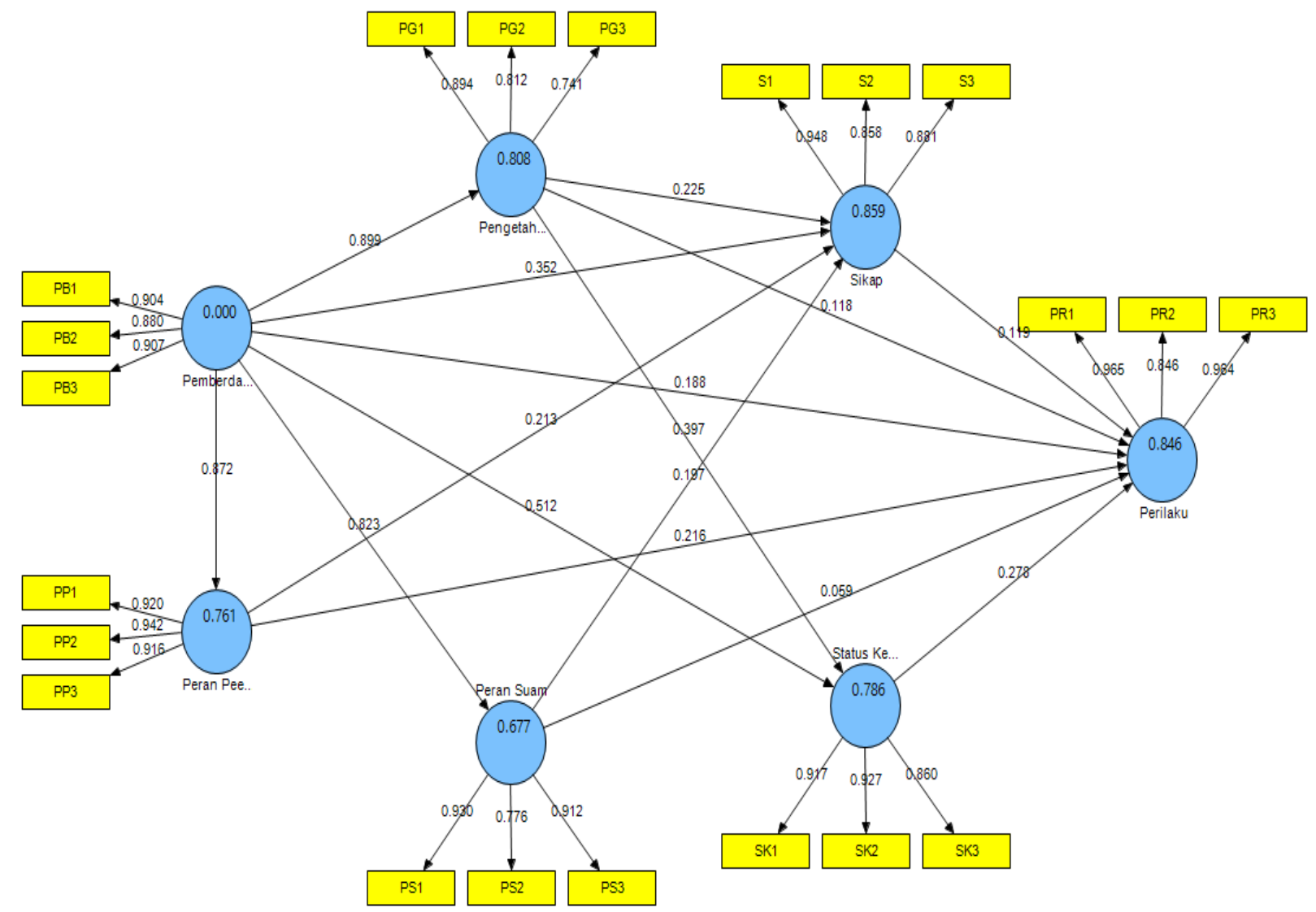

Gambar 1. Output PLS (Loading Factors)

Gambar 1 menjelaskan bahwa semua variabel bersifat refleksif. Indikator merupakan representasi dari masing-masing variabel tercermin dari arah panah yang terbentuk. Untuk variabel pemberdayaan indikatornya adalah konseling, motivasi, kesadaran diri, untuk variabel peran suami indikatornya adalah informasi, instrumental, emosional, untuk variabel peran peer group indikatornya adalah informasi, instrumental, emosional, untuk variabel status kesehatan indikatornya adalah kesehatan fisik, kesehatan mental, kesehatan social, untuk variabel pengetahuan indikatornya adalah kemampuan mengingat penyebab masalah, memahami cara pencegahan, mampu memahami pemeliharaan kesehatan dan untuk variabel sikap indikatornya adalah arah, intensitas, minat.

Semua indikator memiliki loading factor lebih besar dari $0,5(>0,5)$ yang berarti semua indikator merupakan indikator yang valid untuk mengukur konstruknya, dengan demikian semua indikator atas variabel laten lolos uji validitas. Reliabel adalah nilai Composite
Reliability harus diatas uji yaitu lebih besar dari 0,7 (>0,7). Dapat terlihat bahwa composite reliability masing-masing konstruk >0,70, hal ini berarti semua konstruk penelitian sudah reliabel. Untuk nilai AVE untuk semua konstruk $>0,5$ sehingga dapat disimpulkan bahwa evaluasi pengukuran model memiliki diskriminan validity yang baik atau valid dalam mengukur konstruk.

Nilai Cronbach's Alpha sebagian besar memiliki nilai lebih besar dari $0,7 \quad(>0,7)$ sehingga dapat dikatakan bahwa konstruk memiliki reliabilitas yang baik. Nilai $L V$ pemberdayaan terhadap perilaku pencegahan sebesar 0,881 , nilai $L V$ peran suami terhadap perilaku pencegahan adalah sebesar 0,807 , nilai $L V$ peran peer group terhadap perilaku pencegahan adalah sebesar 0,847 , nilai $L V$ pengetahuan terhadap perilaku pencegahan adalah sebesar 0,850 , nilai $L V$ status kesehatan terhadap perilaku pencegahan adalah sebesar 0,876 dan nilai $L V$ sikap terhadap perilaku pencegahan adalah sebesar 0,881 . Sehingga dikatakan bahwa konstruk memiliki reliabilitas 
yang baik. Tabel output PLS dapat dilihat pada gambar 2 berikut ini :

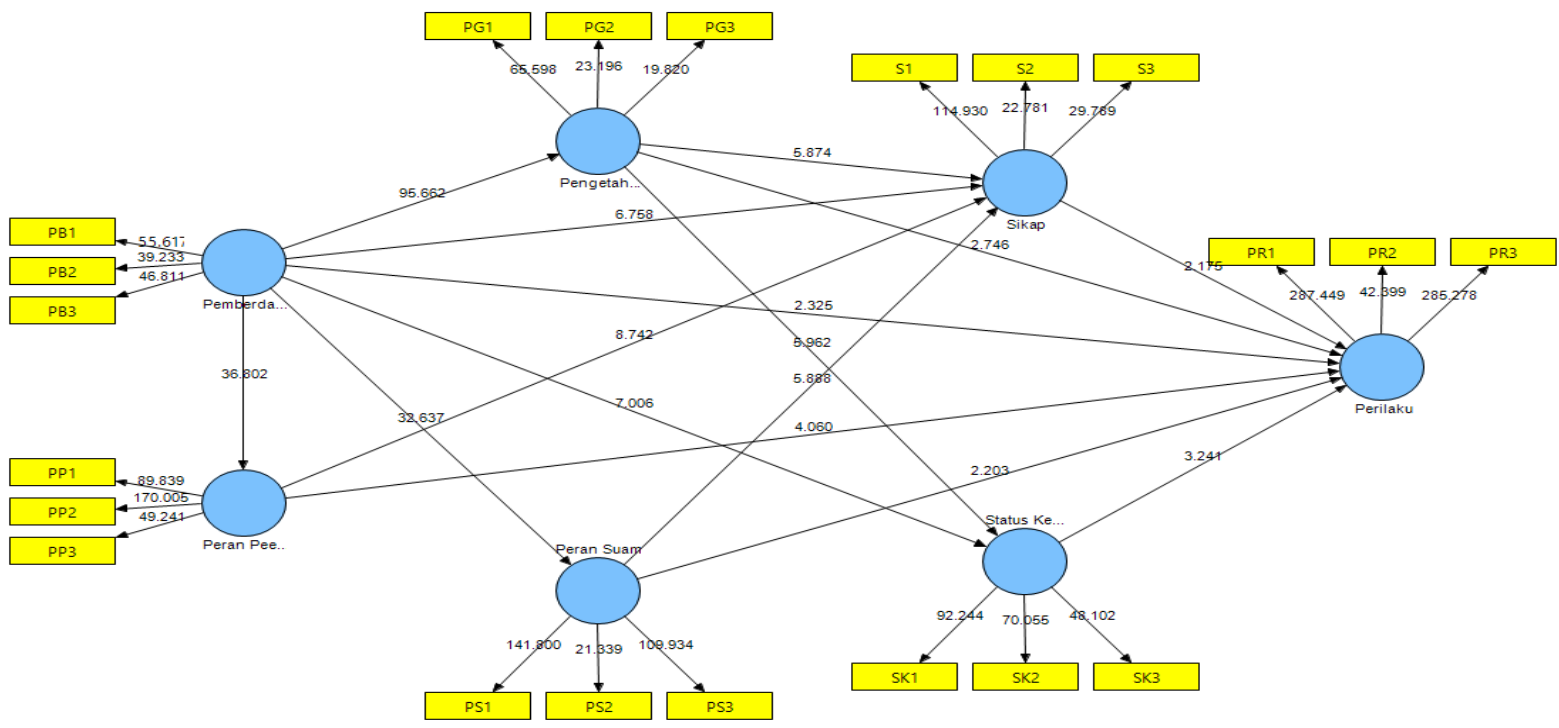

Gambar 2. Output PLS (T-Statistik)

Gambar 2 mendeskripsikan bahwa pemberdayaan memiliki pengaruh yang positif terhadap peran suami (nilai T-Statistik yaitu 32,636, signifikan pada $\alpha=5 \%$, nilai T-Statistik $>$ nilai kritis $(1,96))$. Pemberdayaan memiliki pengaruh positif terhadap peran peer group, adanya pengaruh positif yaitu 0,8722 , nilai $\mathrm{T}$ Statistik adalah 36,802 , signifikan pada $\alpha=5 \%$. Pemberdayaan memilki pengaruh positif terhadap pengetahuan, terdapat pengaruh yang positif 0,89 , nilai $\mathrm{T}$-Statistik yaitu 95,662 , signifikan pada $\alpha=5 \%$. Pemberdayaan memiliki pengaruh positif terhadap status kesehatan, terdapat pengaruh yang positif 0,512 , nilai $\mathrm{T}$ Statistik yaitu 7,0056 signifikan terhadap $\alpha=5 \%$. Pemberdayaan berpengaruh positif terhadap sikap, ada pengaruh positif sebesar 0,352 , sedangkan nilai T-Statistik sebesar 6,7581 dan signifikan pada $\alpha=5 \%$. Pemberdayaan berpengaruh positif terhadap perilaku pencegahan, pengaruh positif 0,1881 , nilai T-Statistik yaitu 2,3246, signifikan pada $\alpha=5 \%$.

Peran suami berpengaruh positif terhadap sikap, hasil uji menunjukkan ada pengaruh positif 0,1968 , nilai T-Statistik sebesar 5,8884, signifikan pada $\alpha=5 \%$, nilai TStatistik > 1,96. Peran suami berpengaruh positif terhadap perilaku pencegahan, menunjukkan ada pengaruh positif 0,059 , nilai
T-Statistik sebesar 2,20 dan signifikan pada $\alpha=5 \%$, nilai $\mathrm{T}$-Statistik > nilai kritis $(1,96)$. Peran peer group berpengaruh positif terhadap sikap, hasil uji menunjukkan ada pengaruh positif 0,2131 , nilai T-Statistik sebesar 8,7424, signifikan pada $\alpha=5 \%$, nilai T-Statistik > 1,96. Peran peer group berpengaruh positif terhadap perilaku pencegahan, ada pengaruh positif 0,2159, nilai T-Statistik sebesar 4,0602, signifikan pada $\alpha=5 \%$, nilai T-Statistik > 1,96.

Pengetahuan berpengaruh positif terhadap status kesehatan, hasil uji menunjukkan ada pengaruh positif 0,3972 , nilai T-Statistik sebesar 5,9619, signifikan pada $\alpha=5 \%$, nilai T-Statistik > 1,96. Pengetahuan berpengaruh positif terhadap sikap, hasil uji menunjukkan ada pengaruh positif 0,2254 , nilai T-Statistik sebesar 5,873, signifikan pada $\alpha=5 \%$, nilai T-Statistik > 1,96. Pengetahuan berpengaruh positif terhadap perilaku pencegahan, hasil uji menunjukkan ada pengaruh positif 0,1184 , nilai $\mathrm{T}$-Statistik sebesar 2,7457, signifikan pada $\alpha=5 \%$, nilai TStatistik > 1,96.

Status kesehatan mempunyai pengaruh positif terhadap perilaku pencegahan, pengaruh positif yaitu 0,2783, nilai T-Statistik 3,2407, signifikan pada $\alpha=5 \%$, T-Statistik > 1,96. Sikap mempunyai pengaruh yang positif terhadap 
perilaku pencegahan, menunjukkan adanya pengaruh positif yaitu 0,119 , nilai T-Statistik 2,175 dan signifikan pada $\alpha=5 \%$, nilai $T$ Statistik lebih dari 1,96.

Tabel 1. Persentase Pengaruh Antar Variabel Penelitian

\begin{tabular}{|c|c|c|c|c|c|c|c|}
\hline Sumber & $\begin{array}{c}L V \\
\text { Correlation }\end{array}$ & $\begin{array}{c}\text { Direct } \\
\text { Path }\end{array}$ & $\begin{array}{c}\text { Inderect } \\
\text { Path }\end{array}$ & Total & $\begin{array}{c}\text { Direct } \\
\%\end{array}$ & $\begin{array}{c}\text { Indirect } \\
\%\end{array}$ & $\begin{array}{c}\text { Total } \\
\%\end{array}$ \\
\hline Pemberdayaan & 0,881 & 0,188 & 0,693 & 0,881 & 16,58 & 1,00 & 17,58 \\
\hline Peran Suami & 0,807 & 0,059 & 0,023 & 0,083 & 4,80 & 0,01 & 4,80 \\
\hline Peran Peer Group & 0,847 & 0,216 & 0,025 & 0,241 & 18,30 & 0,02 & 18,32 \\
\hline Pengetahuan & 0,850 & 0,118 & 0,137 & 0,256 & 10,07 & 0,07 & 10,14 \\
\hline Status Kesehatan & 0,876 & 0,278 & & 0,278 & 24,37 & & 24,37 \\
\hline Sikap & 0,881 & 0,119 & & 0,119 & 10,50 & & 10,50 \\
\hline \multicolumn{5}{|c|}{ Total } & 84,61 & 1,10 & 85,72 \\
\hline
\end{tabular}

Tabel 1 menyatakan bahwa pengaruh pemberdayaan terhadap perilaku pencegahan didapatkan adanya pengaruh langsung sebesar $16,58 \%$, sedangkan untuk pengaruh tidak langsung antara pemberdayaan dan perilaku pencegahan melalui peran suami, peran peer group, pengetahuan, status kersehatan maupun sikap didapatkan nilai sebesar $1,00 \%$. Untuk pengaruh peran suami terhadap perilaku pencegahan didapatkan adanya pengaruh langsung sebesar $4,80 \%$, sedangkan untuk pengaruh tidak langsung antara peran suami terhadap perilaku pencegahan melalui pengetahuan, status kesehatan maupun sikap didapatkan nilai sebesar $0,01 \%$.

Untuk pengaruh variable peran peer group terhadap perilaku pencegahan didapatkan pengaruh secara langsung sebesar $18,30 \%$, sedangkan untuk pengaruh tidak langsung antara Peran Peer Group terhadap perilaku pencegahan melalu pengetahuan, status kesehatan maupun sikap didapatkan nilai sebesar $0,02 \%$. Untuk pengaruh pengetahuan terhadap perilaku pencegahan didapatkan pengaruh langsung sebesar $10,07 \%$, sedangkan pengaruh tidak langsung antara pengetahuan terhadap perilaku pencegahan melalui pemberdayaan, status kesehatan dan sikap didapatkan nilai sebesar $0,07 \%$. Pengaruh status kesehatan terhadap perilaku pencegahan didapatkan adanya pengaruh langsung sebesar 24,37\%.

Pengaruh langsung variabel laten independen tersebut apabila secara bersamasama menunjukkan kesesuaian dengan nilai $R$ Square atau menyatakan bahwa variabel pemberdayaan, variabel peran suami, variabel peran peer group, variabel pengetahuan, variabel status kesehatan dan variabel sikap mampu menjelaskan variabel perilaku pencegahan sebesar $84,61 \%$, sedangkan hasil pengaruh tidak langsung sebesar $1,10 \%$, jadi total pengaruh langsung dan tidak langsung sebesar $85,71 \%$.

\section{PEMBAHASAN}

Pengaruh langsung pemberdayaan lebih besar nilainya dibandingkan dengan pengaruh tidak langsung dan signifikan, ada pengaruh yang positif dari kedua variabel tersebut. Nilai $\mathrm{T}$ statistik menunjukkan bahwa ada pengaruh langsung dan pengaruh tidak langsung antara pemberdayaan terhadap perilaku dalam pencegahan perdarahan post partum.

Pemberdayaan tidak hanya meningkatan status kesehatan, pengetahuan, sikap dan perilaku saja tetapi juga dapat memperbaiki lingkungan fisik dan non fisik dalam rangka memelihara dan meningkatkan kesehatan masyarakat. ${ }^{(15)}$ Penulis menganalisis bahwa pemberdayaan ibu hamil melalui konseling dapat lebih mudah dipahami, sasaran lebih tepat sehingga ibu memutuskan untuk mengadopsi perilaku yang positif khususnya berperilaku yang dapat mencegah terjadinya perdarahan post partum. Pemberdayaan ibu hamil tidak dapat lepas dari adanya peran suami, peran peer group atau teman sesame hamil, status kesehatannya, pengetahuan serta dan sikap w3anita hamil tersebut terhadap perilaku pencegahan perdarahan pasca persalinan. 
Pengaruh tidak langsung antara pemberdayaan terhadap perilaku ibu hamil dalam pencegahan perdarahan post partum lebih didominasi oleh faktor pemberdayaan. Hasil ini dengan penelitian Sugiarti yang menyatakan bahwa pengetahuan mempengaruhi sikap dan perilaku ibu hamil seperti pemeriksaan kehamilan teratur sebagai salah satu pencegahan faktor resiko terjadinya komplikasi, pengetahuan ibu hamil yang baik akan mampu mendeteksi, menilai sendiri kehamilan resiko tinggi sejak awal kehamilannya sehingga perilaku ibu hamil ke arah positif seperti dapat melakukan pencegahan perdarahan post partum. ${ }^{(16)}$

Pengaruh langsung peran suami terhadap perilaku ibu hamil dalam pencegahan perdarahan post partum terbukti secara empiris memiliki pengaruh. Peran suami berpengaruh terhadap perilaku ibu hamil. Hal ini sesuai dengan teori yang menyatakan peran suami dapat meningkatkan perilaku istri yang positif, suami bertanggung jawab secara sosial dan ekonomi sehingga keterlibatan suami dalam ikatan yang lebih kuat diantara mereka dan keturunannya, suami sebagai partner istri dalam reproduksi dan seksual sehingga sangat beralasan untuk berbagi tanggung jawab secara seimbang untuk kehidupan keluarganya. ${ }^{(17)}$

Penelitian lain menyatakan bahwa peran suami adalah variabel yang dominan dalam mempengaruhi istri melakukan perawatan kehamilan. ${ }^{(18)}$ Sesuai juga dengan penelitian Istiqomah menyatakan terdapat pengaruh peranan suami terhadap pengetahuan ibu hamil, berpengaruh pada perilaku ibu hamil seperti konsumsi suplementasi zat besi sebagai salah satu pencegahan terhadap perdarahan post partum. ${ }^{(9)}$. Analisa peneliti yaitu bahwa pengaruh peran suami secara langsung memberikan dampak positif untuk perilaku ibu hamil khususnya dalam pencegahan perdarahan pasca persalinan yaitu seperti menemani istri yang hamil pada saat pemeriksaan kehamilan, memberikan biaya pemeriksaan istri, memberikan biaya untuk membeli nutrisi yang bergizi bagi istri, mengkonsumsi suplementasi zat besi dan pemeriksaan kehamilan ke tenaga kesehatan, merencanakan jumlah anak, jarak kelahiran yang aman, pencegahan anemia karena anemia salah satu penyebab terbesar terjadinya perdarahan setelah persalinan.

Peran peer group adalah peranan dari teman sesama ibu hamil yang siap dalam memberikan bantuan berupa informasi tentang kesehatan dalam kehamilan. Secara umum individu mempunyai perilaku yang saling mempengaruh seperti saling perhatian, mengingatkan dan fantasi, mempunyai motif untuk berhubungan atau berinteraksi dengan orang lain, peran peer group mempunyai peran yang penting dalam mensuport kehamilan yang sehat. ${ }^{(17)}$ Hasil ini sesuai dengan penelitian Mite menyatakan bahwa terdapat pengaruh peran peer group terhadap perilaku ibu hamil, peran peer groupmempunyai pengaruh yang signifikan terhadap pengetahuan, sikap dan perilaku ibu hamil dalam mengatasi masalah kehamilan. ${ }^{(11)}$

Analisa peneliti peran peer group atau peran teman sesama ibu hamil mempunyai peran yang penting secara langsung dalam mensuport wanita yang hamil, yang mempunyai pemahaman dan meningkatkan pengetahuan mereka tentang kehamilan yang sehat, sehingga sikap mereka yang positif akan mempengaruhi perilaku wanita hamil yang sehat secara fisik jiwa serta sosial, sehingga terhindar dari salah satu kegawatdaruratan kebidanan seperti perdarahan pasca persalinan.

Pengaruh langsung status kesehatan terhadap perilaku memiliki pengaruh yang signifikan dan bernilai positif. Sesuai dengan teori WHO, status kesehatan merupakan suatu keadaan sejahtera secara fisik, mental dan sosial dan bukan sekedar tidak memiliki penyakit. ${ }^{(19)} \mathrm{Hal}$ ini sesuai dengan penelitian ${ }^{(20)}$ menyatakan bahwa status kesehatan dipengaruhi oleh pengetahuan, semakin baik pengetahuan ibu maka status kesehatan ibu hamil semakin baik dan status kesehatan mempengaruhi perilaku ibu hamil yaitu semakin baik status kesehatan semakin baik pula perilaku ibu hamil dalam perawatan kehamilannya. Analisis peneliti menyatakan bahwa status kesehatan ibu hamil dalam kondisi baik atau buruk akan mempengaruhi perilaku dalam pencegahan perdarahan post partum. Ibu hamil harus dapat mencegah penyakit, mencegah perilaku kesehatan yang negatif yang berbahaya bagi kesehatan seperti diet yang buruk dan penolakan untuk konsumsi 
vitamin. Status kesehatan yang baik akan mempengaruhi perilaku ibu yang positif sehingga dapat membantu menjaga selama kehamilan, kelahiran dan setelah persalinan. dengan status kesehatan yang baik diharapkan memiliki perilaku yang positif khususnya dalam pencegahan dini perdarahan pasca persalinan.

Pengaruh langsung pengetahuan terhadap perilaku pencegahan perdarahan post partum terbukti secara empiris memiliki pengaruh. Pengetahuan berpengaruh terhadap perilaku ibu hamil dengan nilai $T$ sebesar 2,75, signifikan pada nilai alpha $\alpha=5 \%$, nilai $\mathrm{T}$ statistik tersebut di atas nilai kritis $(T>1,96)$. Nilai pengaruh langsung pengetahuan terhadap perilaku memiliki pengaruh yang signifikan dan bernilai positif. Hasil ini sesuai dengan teori pengetahuan yaitu suatu yang diketahui atau yang dimiliki seorang individu melalui pendidikannya maupun pengalamannya. ${ }^{(15)}$

Sesuai dengan hasil penelitian tentang pendampingan wanita hamil resiko tinggi menyatakan bahwa pengetahuan ibu hamil yang masih kurang dapat mempengaruhi perilaku ibu yaitu tidak teratur dalam pemeriksaan kehamilannya, mengatakan periksa hamil cukup dua kali saja yaitu awal kehamilan dan akhir kehamilan atau pada saat mendekati persalinan. $^{(8)}$ Analisis peneliti bahwa pengetahuan yang baik akan mempengaruhi perilaku ibu hamil yang positif seperti mengetahui, memahami dan dapat melakukan pemeriksaan kehamilan secara teratur yaitu minimal 4 kali kunjungan sehingga resiko tingi kehamilan dapat lebih awal dikenali, melakukan pemeriksaan teratur merupakan salah satu perilaku ibu hamil dalam pencegahan perdarahan setelah persalinan.

Nilai pengaruh langsung sikap terhadap perilaku memiliki pengaruh yang signifikan dan bernilai positif. Sesuai dengan teori sikap yaitu kecenderungan untuk merespon secara positif maupun negatif terhadap orang, objek atau situasi tertentu, mengandung penilaian emosional afektif (senang, benci, sedih) faktor yang ada dalam diri seseorang yang dapat mendorong perilaku seseorang. ${ }^{(21)}$

Sesuai dengan penelitian Roozbeh yaitu sikap wanita hamil akan berpengaruh pada perilaku wanita hamil tersebut, sikap wanita hamil yang negatif terhadap kesehatannya adalah salah satu hambatan untuk memeriksakan kehamilannya. ${ }^{(22)}$ Analisis peneliti yaitu sikap ibu hamil yang positif akan mempengaruhi perilaku ibu hamil yang positif pula dalam pencegahan perdarahan pasca persalinan, perilaku yang positif seperti ibu hamil melakukan anjuran petugas kesehatan (bidan) seperti pemeriksaan kehamilan yang teratur akan diketahui lebih dini masalah ataupun komplikasi dalam kehamilan dan persalinan khususnya dalam pencegahan terjadinya perdarahan setelah persalinan.

\section{SIMPULAN DAN SARAN}

Kesimpulan penelitian ini yaitu status kesehatan merupakan faktor yang paling dominan mempengaruhi perilaku ibu hamil dalam pencegahan perdarahan pasca persalinan di RS Kesdam Cijantung tahun 2019. Dan peran suami menjadi faktor yang paling sedikit pengaruhnya terhadap perilaku ibu hamil dalam pencegahan perdarahan pasca persalinan di RS Kesdam Cijantung.

Diharapkan seluruh sektor bekerja sama untuk menguatkan perilaku ibu hamil dalam melakukan pencegahan lebih awal, yaitu perilaku mencegah terjadinya perdarahan pasca persalinan baik dari faktor pemberdayaan, peran suami, peran peer group, status kesehatan, pengetahuan dan sikap. Dari masa hamil sudah dipersiapkan kegiatan promosi hidup sehat dan deteksi dini sebagai strategi pencegahan perdarahan pasca persalinan. Status kesehatan ibu hamil yang baik akan mempengaruhinya untuk berperilaku yang positif khusunya dalam mencegah terjadinya perdarahan pasca persalinan. Pasca persalinan yang aman menjadikan keberlangsungan kondisi ibu dan bayi tetap sehat.

\section{Daftar Pustaka}

1.WHO.https://sustainabledevelopment.un.org/sdg s. 2018.

2. Kemenkes RI. Buku Kesehatan Ibu dan Anak. Jakarta: Kemenkes RI; 2016.

3. Jakarta DKPD. Profil Kesehatan Provinsi DKI Jakarta Tahun 2016. In Jakarta; 2016.

4. Sulastri. Model Pencegahan Anemia Pada Ibu Hamil Untuk Menurunkan Perdarahan Post Partum. J UMS. 2012;1.

5. Bhisma M et all. Risk Factor of Post partum Hemorraghea in Bondowoso District, East 
Java. J Matern Child Heal. 2017;2:177-8.

6. Counselling Improves Anemia Prevention attitude of Pregnant Women. Ners J. 2017;4:149-54.

7. Rochima D. Komunikasi dan Konseling Dalam Praktik Kebidanan. Jakarta: Tran info Media; 2010.

8. Ratnaningsih D. Pendampingan Wanita Hamil di Program RisikoTinggi (Gerdaristi) untuk Mengurangi Angka Kematian Ibu dan bayi di Nganjuk Jawa Timur. J Kesehat Ibu dan Anak. 2016;1:268-76.

9. Istiqomah. Peranan Suami dalam Mempengaruhi Keputusan Ibu Hamil Untuk Mengkonsumsi Tablet Besi. Nurs J (Manila). 2013;

10. Armini D. The Beneficience of Family Social Support Toward Anticipatory Behaviour of Pregnanccies Sign's Allert in Primigravida. Ners J. 2013;3.

11. Mite Maria. Pengaruh Metode Peer Group Pada Ibu Hamil dengan Anemia terhadap Pengetahuan Mengenal Tanda Bahaya Kehamilan, Persalinan, Nifas. J Nurs. 2018;1.

12. Ghozali I. Aplikasi Analisis Multivariate Dengan Program IBM SPSS 21 Update PLS Regresi. 7th ed. Semarang: Badan Penerbit Undip; 2016.

13. Hair F, J. et all. A Primer on Partial Least Square Structural Equation of Modelling (PLS-SEM). Amerika: SAGE publication IN; 2014.

14. Suharsimi A. Pengembangan Instrumen Penelitian. Pelajar P, editor. Jogjakarta; 2017.

15. Notoatmodjo S. Promosi Kesehatan dan Perilaku Kesehatan. Jakarta; 2014.

16. Sugiarti dkk. Upaya Pemberdayaan Ibu Hamil Untuk Deteksi Dini Resiko Tinggi Kehamilan. Indones J Public Heal. 2012;9.

17. Clara D. Psikologi Sosial. Jakarta: Salemba Humanika; 2018.

18. Gamelia et all. Determinant of Mother's Prenatal care Behavior. J Kesehat Masy Nas. 2013;8:109-15.

19. Potter \& Perry. Fundamental Keperawatan. 7th ed. Potter\& Perry, editor. Jakarta: Salemba Medika; 2010.

20. Berliana S. Faktor-faktor Status Kesehatan Pada Ibu Hamil. J USU. 2012;4.

21. Kuswana. Biopsikologi Pembelajaran Sikap dan Perilaku. Bandung: Alfabeta; 2014.

22. Roozbeh et all. Associated with Utilizing PreNatal Care Among Women. saudi Med Journals. 2016;37:1319-27. 